\title{
Nutrient Composition of Dust Emitted from Poultry Broiler Houses in Northwest Arkansas
}

\author{
Sheri L. Herron1, Kristofor R. Brye ${ }^{1 *}$, Andrew N. Sharpley¹, David M. Miller ${ }^{1}$, \\ Mike B. Daniels ${ }^{2}$ \\ ${ }^{1}$ Department of Crop, Soil, and Environmental Sciences, University of Arkansas, Fayetteville, AR, USA \\ ${ }^{2}$ Department of Crop, Soil, and Environmental Sciences, South University Avenue, Little Rock, AR, USA \\ Email: "kbrye@uark.edu
}

Received 10 October 2015; accepted 10 November 2015; published 13 November 2015

Copyright (C) 2015 by authors and Scientific Research Publishing Inc.

This work is licensed under the Creative Commons Attribution International License (CC BY). http://creativecommons.org/licenses/by/4.0/

(c) (i) Open Access

\begin{abstract}
A substantial body of research has been conducted on the potential water quality impairments associated with land application of poultry broiler litter. However, until recently, little attention has focused on the potential for nutrient runoff from dust emitted from broiler production houses despite related air quality concerns raised by the United States (US) Environmental Protection Agency. The objective of this study was to characterize the composition of broiler house dust (BHD) and compare BHD composition to that of broiler litter (BL). Dust composition varied significantly $(P<0.05)$ among facilities operated by different integrator companies, likely due to differences in feed and house management among integrators. Specifically, BHD pH was lower $(P<0.05)$ in Facility 1 than in Facilities 2 and 3, which did not differ, whereas BHD $K$ and Ca were greatest $(P<$ 0.05 ) in Facility 1 and 2, respectively. The facility average moisture content of BHD was at least 1.9 times lower than that for the BL from the same facility. The facility average total phosphorus (TP) and water extractable phosphorus (WEP) concentrations in BHD were at least 1.2 and 1.6 times greater, respectively, than that for BL from the same facility. The greater WEP in BHD than in BL is of particular environmental importance given that extensive research shows WEP to be a major variable influencing $P$ runoff risk. The facility average total nitrogen (TN) concentration in BHD was at least 3.0 times greater than that for BL from the same facility. As TP, WEP, and TN are greater in BHD than in BL, there is a greater risk of nutrient enrichment of runoff from an equivalent mass of BHD than BL. The results of this study highlight the need for careful management of dust emissions from broiler houses and a need for conservation practices to minimize the risk of BHD increasing nutrient runoff and its loss to waters of the US.
\end{abstract}

\footnotetext{
${ }^{*}$ Corresponding author.
}

How to cite this paper: Herron, S.L., Brye, K.R., Sharpley, A.N., Miller, D.M. and Daniels, M.B. (2015) Nutrient Composition of Dust Emitted from Poultry Broiler Houses in Northwest Arkansas. Journal of Environmental Protection, 6, $1257-1267$. 
Keywords

Broiler House Dust, Broiler Litter, Nutrient Runoff, Surface Water Quality

\section{Introduction}

Broiler house dust (BHD) emissions have recently gained the attention of the United States (US) Environmental Protection Agency (EPA), as concerns increase over air and water quality issues associated with broiler production facilities [1]. These concerns center mainly on the release of phosphorus $(\mathrm{P})$ and nitrogen $(\mathrm{N})$ into the environment as a result of BHD emissions. The broiler production houses to which EPA is referring include broiler chickens (Gallus gallus domesticus), broiler egg-laying hens, and turkeys (Meleagris gallopavo), which are all produced on dry bedding materials. The bedding material is typically comprised of wood shavings, rice (Oryza sativa) hulls, peanut (Arachis hypogaea) hulls, sand, or a combination of these.

The concentration of broiler operations in northwest AR, which is second only to GA in annual broiler production (i.e., by weight) in 2014 [2], has led to extensive research on the contribution of broiler operations and land application of litter on area pastures to $\mathrm{P}$ and $\mathrm{N}$ enrichment of surface waters [3] [4]. Fueled by several ongoing lawsuits in northwest AR and the Chesapeake Bay Watershed [1] [5] [6], this led to an urgent need for reliable information on the relative contributions of these and numerous other sources of $\mathrm{P}$ and $\mathrm{N}$ inputs to area streams and lakes at a watershed scale. However, little research has been conducted regarding the composition or fate of nutrients in dust emitted from broiler production houses to the environment.

Dust from broiler production facilities is the fine particulate portion of broiler litter that is a combination of feathers, fecal material, skin, spilled feed, mold spores, bacteria, fungus, and bedding fragments [7], which is commonly expelled from the broiler house through sidewall and tunnel ventilation fans. Fans at broiler production houses are operated for different purposes and at different times during a flock production cycle, which greatly affects the amount of dust exhausted by each fan. There are two modes of fan operation, desired room temperature and minimum ventilation. Fans are operated to maintain the in-house temperature at a desired level, and to provide the required air quality needed by the birds. Sidewall fan use dominates during cooler weather. Tunnel fan use is greater during warmer weather and each tunnel fan exhausts at a rate that is approximately 2.5 times greater than a sidewall fan, resulting in significantly more dust being exhausted from the house during tunnel ventilation fan use.

An EPA study conducted in Kentucky estimated that a single broiler house emits greater than $785 \mathrm{~kg}$ of dust per year [8]. The US produces approximately 8.4 billion broiler chickens annually for consumer consumption [9]. Considering that there are approximately 61,301 broiler houses in the US, this equates to an estimated 48,000 Mg (or 48,000 tonnes) of dust emitted annually from broiler houses. Figure 1 depicts dust deposited on the ground adjacent to broiler house tunnel ventilation fans, and shows the exposure of the site to natural rainfall and subsequent potential runoff from the site.

While EPA has conducted studies to quantify dust emissions, little data are available regarding the nutrient composition of the BHD as it relates to water quality impairment. In order to accurately estimate the potential contribution of dust emitted from broiler houses to nutrient runoff, a detailed physical and chemical analysis of the BHD is needed. As the nutrient composition of BHD likely varies with bedding material type, management and integrator feed composition, an evaluation of BHD composition among facilities representing different integrators is warranted. A concurrent analysis of broiler litter (BL) would allow for comparison of the composition of dust and litter from which the BHD originated.

The objectives of this study were to characterize BHD and BL composition among various facilities in northwest AR and to evaluate the effects of fan type, fan location, and time of year on dust composition within a single facility. It was hypothesized that the nutrient composition of BHD would vary among integrator facilities due to differences in feed composition and house management, and that BHD composition would be similar to source BL. It was further hypothesized that there would be no differences in dust composition between sidewall and tunnel fans at a given facility. However, BHD composition from fans at the same facility was expected to vary during a year with house management and weather. One unique aspect of this research was the ability to collect samples from two private facilities and a University-of-Arkansas-operated facility, where all operated on a commercial basis for three different integrators. 


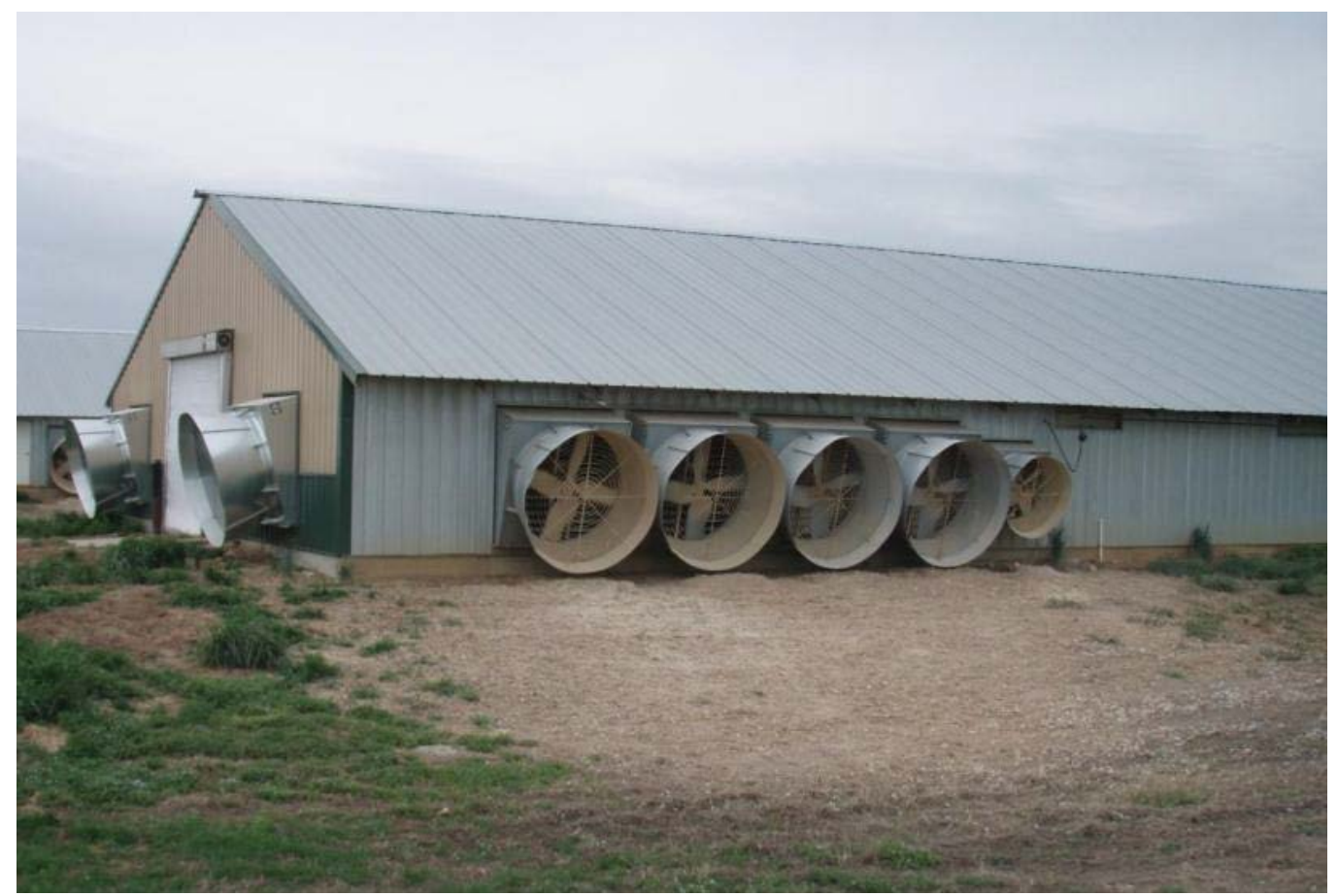

Figure 1. Picture of dust deposited adjacent to broiler house tunnel ventilation fans (photograph credit goes to EPA Region 6, 2013).

\section{Materials and Methods}

\subsection{Site Description}

A single, representative contract broiler production facility was identified for each of the three primary broiler producing companies (i.e., integrators) in northwest AR. As dust is emitted from the houses by ventilation fans, residual amounts settle on fan shutters and bird barriers (i.e., screens on the inside of the fans to prevent birds from entering the fan box). The two types of broiler house fans, sidewall and tunnel ventilation fans have a typical average flow of 227 and $566 \mathrm{~m}^{3} \cdot \mathrm{min}^{-1}$, respectively. Dust was collected from both types of fans.

\subsection{Experimental Design}

As every broiler production facility is managed slightly differently for air quality and bird health, this study was a survey to establish a baseline comparison between BHD and BL across various integrators in northwest AR. The experiment was treated as a block design, with the independent variable being the integrator and the dependent variables being the nutrient composition of BHD and BL.

\subsection{Litter and Dust Sample Collection}

Collection of BHD occurred within three days of bird removal from a house and prior to any in-house cleaning between flocks, and after at least three flocks of birds had been produced on the same bedding material. Based on personal experience, after three flocks, the in-house uniformity of BL composition generally increases. Broiler house dust was collected on rain-free days to minimize any fluctuations in sample moisture due to ambient humidity.

Broiler litter samples were collected from the production house prior to litter cleanout by standard sampling protocols that involved collecting 10 grab samples, from the surface to the floor, which was approximately 15$\mathrm{cm}$ deep, in a zig-zag pattern within the house. Samples were combined, mixed, and subsampled to create one representative, composite sample for each facility.

A sampling protocol was established for obtaining consistent dust samples. Dust was collected inside the broiler houses from the tops of fan shutters and bird barriers. As BHD is extremely light and disperses easily 
unless air movement within the facility is minimal, all fans were turned off while sampling. Dust from each fan was sampled and stored independently. A 2.5-cm-wide brush was used to brush dust into a plastic dustpan with a hollow handle. Samples were stirred in the dustpan with a clean spatula. The handle of the dustpan was placed inside the sample container and the brush was used to sweep the dust into the container through the dustpan handle. Once filled, sample containers were immediately capped to avoid contamination. Surplus dust from the composite sample in the dustpan was discarded. Between sampling each fan, all materials were thoroughly cleaned to minimize any cross-contamination of BHD. If there was not a sufficient amount of BHD present to conduct the required analyses (i.e., about $10 \mathrm{~g}$ ), this was recorded and no sample was collected. Sampling for replications of BHD was limited by available dust volume and resulted in five samples from Facility 1, 29 samples from Facility 2, and 10 samples from Facility 3. Additional sampling occurred periodically after each flock for one year from the sidewall ventilation fans at House 4 of Facility 2. Table 1 summarizes the date, fan type sampled, and the number of dust samples collected on each date from each facility.

Samples were transported immediately following collection to the University of Arkansas, Agricultural Diagnostic Laboratory (Fayetteville, AR) or shipped to A\&L Laboratories (Memphis, TN) for nutrient analyses. In all cases, samples were analyzed in triplicate.

\subsection{Chemical Analyses of Broiler Litter and Broiler House Dust}

Total $\mathrm{P}$, calcium $(\mathrm{Ca})$, potassium $(\mathrm{K})$, and magnesium $(\mathrm{Mg})$ were determined by inductively coupled plasma optical emission spectroscopy (ICP-OES) (PerkinElmer Optima 7300, Waltham, MA) after ashing $1.0 \mathrm{~g}$ of BHD or $\mathrm{BL}$ in a muffle furnace at $550^{\circ} \mathrm{C}$ for 4 hours. Ash was dissolved in $10 \mathrm{~mL}$ of concentrated $\mathrm{HCl}$, transferred to $100 \mathrm{~mL}$ volumetric flasks and diluted to volume with distilled water [10]. Moisture content of the BHD and BL

\begin{tabular}{|c|c|c|c|c|}
\hline Facility & Date Sampled & Production House & Fan Type & Number of Samples \\
\hline \multirow{5}{*}{1} & $10 / 5 / 2011$ & 1 & Tunnel & 1 \\
\hline & $10 / 5 / 2011$ & 2 & Tunnel & 1 \\
\hline & $10 / 5 / 2011$ & 3 & Tunnel & 1 \\
\hline & $10 / 5 / 2011$ & 4 & Tunnel & 1 \\
\hline & $10 / 5 / 2011$ & 5 & Tunnel & 1 \\
\hline \multirow{6}{*}{2} & 9/19/2011 & 1 & Sidewall & 4 \\
\hline & 9/19/2011 & 2 & Sidewall & 4 \\
\hline & 9/19/2011 & 2 & Tunnel & 7 \\
\hline & 9/19/2011 & 3 & Sidewall & 3 \\
\hline & 9/19/2011 & 4 & Sidewall & 4 \\
\hline & 9/19/2011 & 4 & Tunnel & 7 \\
\hline \multirow{10}{*}{3} & 1/9/2012 & 1 & Sidewall & 1 \\
\hline & 1/9/2012 & 2 & Sidewall & 1 \\
\hline & 1/9/2012 & 3 & Sidewall & 1 \\
\hline & 1/9/2012 & 4 & Sidewall & 1 \\
\hline & $1 / 9 / 2012$ & 5 & Sidewall & 1 \\
\hline & $1 / 9 / 2012$ & 6 & Sidewall & 1 \\
\hline & $1 / 9 / 2012$ & 7 & Sidewall & 1 \\
\hline & 1/9/2012 & 8 & Sidewall & 1 \\
\hline & 1/9/2012 & 9 & Sidewall & 1 \\
\hline & 1/9/2012 & 10 & Sidewall & 1 \\
\hline
\end{tabular}


was determined by oven-drying at $110^{\circ} \mathrm{C}$ for 6 hours, which was subsequently used for correction of nutrient concentrations to an oven-dry basis.

Total carbon (C) and total $\mathrm{N}(\mathrm{TN})$ were determined by dry combustion [11]. The $\mathrm{pH}$ of the BHD and BL was determined by standard potentiometric methods [12], and water-extractable P (WEP) was determined by endover-end shaking $1 \mathrm{~g}$ of material with distilled water at a 1:100 ratio for 1 hour at $24.2 \mathrm{rpm}$ [13]. The mixture was centrifuged (Beckman Coulter Allegra X-15R, Pasadena, CA) for 20 minutes at $5250 \times \mathrm{g}$, filtered through a $0.45-\mu \mathrm{m}$ filter, and $\mathrm{P}$ was determined by inductively coupled, argon plasma spectrophotometry. This water extraction is the standard method used across the US to estimate manure-P solubility and is used in site risk assessment of $\mathrm{P}$ loss as a part of the 590 Conservation Standard for nutrient management [14]. Water-extractable P concentration of BHD and BL was calculated as the $\mathrm{P}$ concentration per unit dry weight of litter. Ammonium- $\mathrm{N}\left(\mathrm{NH}_{4}-\mathrm{N}\right)$ and nitrate- $\mathrm{N}\left(\mathrm{NO}_{3}-\mathrm{N}\right)$ concentrations were determined following extraction with $2 \mathrm{M} \mathrm{KCl}$ on an autoanalyzer (Skalar SanPlus, Breda, The Netherlands) using salicylic acid and cadmium reduction methods, respectively [15].

\subsection{Statistical Analyses}

Homogeneity of variance was evaluated among facilities for each dust parameter measured. Separate one-factor analyses of variance (ANOVA) were conducted to evaluate the following: a) the effect of integrator facility on the chemical composition of the BHD, b) differences in the concentration of measured constituents in BHD between fan types and among seasons from House 4 at Facility 2, and c) differences in chemical constituents between BHD and BL based on a randomized complete block design. Linear regression was conducted to evaluate the relationship between water-extractable P and total Ca concentrations in BHD. When appropriate, means were separated by least significant difference at the 0.05 level. All relationships are reported as statistically significant at $P<0.05$, unless otherwise noted. Wolfram Mathematica (online beta version 2014, Wolfram, Champaign, IL) was used to conduct all statistical analyses.

\section{Results and Discussion}

\subsection{General Summary of Dust Sampling}

Based on visual observations, BHD quantity varied among fans within the three facilities and several fans did not contain adequate dust for sampling. This variability was likely due to differences in shutter and protective cover design. For example, some tunnel ventilation fans were covered only by wire protective covers, while others were covered by shutters that have a greater surface area on which dust can settle. At Facility 1, houses only had two sidewall fans per house and five tunnel fans used for both ventilation and temperature control. Thus, at Facility 1, only tunnel ventilation fan shutters contained sufficient dust volumes for composite sampling in October 2011 ( $\mathrm{n}=5$ total). At Facility 2, BHD collected from both sidewall ventilation fan shutters and tunnel ventilation fan bird barriers contained sufficient dust volumes for composite sampling in September $2011 \mathrm{n}=$ 29 total). Also, at Facility 2, four sidewall ventilation fans in House 4 were sampled between each of five production flocks over one year (i.e., approximately every eight weeks) between April 2012 and January 2013 ( $\mathrm{n}=20$ total). At Facility 3, only sidewall ventilation fan shutters contained sufficient dust volumes for composite sampling in January 2012 ( $n=10$ total). Tunnel ventilation fans at this facility were covered by wire protective covers, with little surface area for dust to settle. Table 1 summarizes timing, facility, and fan type for BHD collection.

\subsection{Dust Composition Differences among Facilities}

Dust composition varied between the facilities sampled based on likely differences in integrator feed blends and house management. The $\mathrm{pH}$ of BHD ranged from 7.0 to 7.8 among the three facilities (Table 2). Total N, $\mathrm{NH}_{4}-\mathrm{N}$, and $\mathrm{NO}_{3}-\mathrm{N}$ concentrations in the dust ranged from 69 to $146,2.4$ to 10.3 , and 0.05 to $1.7 \mathrm{~g} \cdot \mathrm{kg}^{-1}$, respectively, while TP and WEP concentrations tended to be more consistent ranging from 11.9 to 20.6 and 3.9 to 8.3 $\mathrm{g} \cdot \mathrm{kg}^{-1}$, respectively (Table 2). Water-extractable P represented between $22.5 \%$ and $54.2 \%$ of TP (Table 2). Table 2 summarizes the minimum, maximum, and variance for all measured BHD properties for each facility.

Among facilities, five of $12 \mathrm{BHD}$ properties measured (i.e., TN, $\mathrm{C}, \mathrm{K}, \mathrm{NH}_{4}-\mathrm{N}$, and $\mathrm{pH}$ ) had significantly different variances $(P<0.05$; Table 2$)$. Total $\mathrm{N}$ concentrations were most variable at Facilities 1 and 3 , while $\mathrm{K}$ concentrations varied most at Facility 3. Carbon concentrations were most variable at Facilities 2 and 3.

In general, these variances demonstrate that BHD composition can vary several fold as a function of house 
Table 2. Summary of minimum, maximum, and variance associated with dust compositions among facilities (F).

\begin{tabular}{|c|c|c|c|c|c|c|c|c|c|c|}
\hline \multirow{2}{*}{ Measured Parameter* } & \multicolumn{3}{|c|}{ Minimum $^{\dagger}$} & \multicolumn{3}{|c|}{ Maximum } & \multicolumn{3}{|c|}{ Variance } & \multirow{2}{*}{$\begin{array}{l}\text { Homogeneity of } \\
\text { Variance Test }(P)\end{array}$} \\
\hline & $\mathrm{F} 1$ & F2 & F3 & F1 & F2 & F3 & F1 & F2 & F3 & \\
\hline $\mathrm{H}_{2} \mathrm{O}(\%)$ & 8.6 & 10.1 & 12.9 & 9.8 & 15.2 & 18.3 & 0.2 & 1.6 & 2.2 & 0.47 \\
\hline DM (\%) & 90.2 & 84.8 & 81.7 & 91.4 & 89.9 & 87.1 & 0.2 & 1.6 & 2.2 & 0.47 \\
\hline $\mathrm{TN}\left(\mathrm{g} \cdot \mathrm{kg}^{-1}\right)$ & 124.2 & 69.0 & 82.2 & 146.0 & 91.8 & 111.8 & 99.3 & 34.0 & 105.4 & 0.01 \\
\hline $\mathrm{C}\left(\mathrm{g} \cdot \mathrm{kg}^{-1}\right)$ & 309.3 & 286.1 & 302.0 & 313.8 & 345.9 & 352.7 & 2.7 & 346.0 & 205.9 & $<0.01$ \\
\hline $\mathrm{TP}\left(\mathrm{g} \cdot \mathrm{kg}^{-1}\right)$ & 13.2 & 13.6 & 11.9 & 15.3 & 20.6 & 17.6 & 0.7 & 2.2 & 3.3 & 0.32 \\
\hline $\mathrm{K}\left(\mathrm{g} \cdot \mathrm{kg}^{-1}\right)$ & 38.8 & 25.5 & 11.9 & 47.4 & 33.1 & 30.3 & 9.9 & 4.2 & 35.4 & $<0.01$ \\
\hline $\mathrm{Ca}\left(\mathrm{g} \cdot \mathrm{kg}^{-1}\right)$ & 15.1 & 21.2 & 0.2 & 16.6 & 31.5 & 17.8 & 0.4 & 4.5 & 21.1 & 0.14 \\
\hline $\mathrm{NH}_{4}-\mathrm{N}\left(\mathrm{mg} \cdot \mathrm{kg}^{-1}\right)$ & 8107 & 2369 & 4617 & 10,304 & 3831 & 5574 & 842,553 & 155,040 & 84,034 & $<0.01$ \\
\hline $\mathrm{NO}_{3}-\mathrm{N}\left(\mathrm{mg} \cdot \mathrm{kg}^{-1}\right)$ & 54.7 & 158.9 & 167.0 & 69.4 & 872.8 & 1727.0 & 46.3 & 39,207 & 205,498 & 0.07 \\
\hline WEP (mg. $\left.\mathrm{kg}^{-1}\right)$ & 5350 & 4715 & 3932 & 6426 & 8313 & 5051 & 233,876 & 722,705 & 130,649 & 0.07 \\
\hline TP as WEP (\%) & 40.3 & 27.4 & 22.5 & 43.9 & 54.2 & 42.4 & 2.3 & 38.1 & 27.4 & 0.12 \\
\hline pH 1:5 & 7.0 & 7.1 & 7.3 & 7.3 & 7.8 & 7.5 & 0.009 & 0.1 & 0.003 & $<0.01$ \\
\hline
\end{tabular}

*Measured parameters include gravimetric moisture (H2O), dry matter (DM), total nitrogen (TN), carbon (C), total phosphorus (TP), potassium (K), calcium (Ca), ammonium nitrogen $(\mathrm{NH} 4-\mathrm{N})$, nitrate nitrogen $\left(\mathrm{NO}_{3}-\mathrm{N}\right)$, water extractable phosphorus (WEP), total phosphorus as water extractable phosphorus (TP as WEP), and $\mathrm{pH}$. $^{\dagger}$ The number of observations included were 5, 26, and 10, from Facility 1, 2, and 3, respectively.

and feed management, which is determined by each integrator. Specifically, variability in BHD C and K concentrations among facilities is likely related to bedding management and bird excretion locations. Bedding materials, such as wood shavings and rice hulls, can contain up to 400 and $50 \mathrm{~g} \cdot \mathrm{kg}^{-1}$ of C and $\mathrm{K}$, respectively [16] [17]. When freshly hatched broiler chicks are placed in a production house, half of the house is generally closed off with curtains while the birds are small to more efficiently help birds retain body heat. After 10 to 14 days, the curtains are removed. This results in uneven distribution of manure throughout the house. The litter (i.e., bedding and feces) in the house is continuously composting, but more rapidly in the half of the house where fresh manure is deposited due to the contribution of moisture, C, N, and P that are consumed by the bacteria to create energy. Where greater rates of composting occur, greater quantities of nutrients in the bedding are available to be adsorbed onto dust particles.

The variability in TN concentrations of BHD among facilities was likely a result of integrator feed composition differences. The variability in $\mathrm{N}$ fractions among facilities was likely related to litter composting rates of nitrifying bacteria as they converted ammonia into nitrite and $\mathrm{NO}_{3}^{-}$. Similar to $\mathrm{N}$ compounds, differences in BHD $\mathrm{pH}$ variability among facilities were also likely a result of integrator feed composition differences. The remaining seven of the $12 \mathrm{BHD}$ properties measured, including moisture content, dry matter, $\mathrm{P}, \mathrm{Ca}, \mathrm{NO}_{3}-\mathrm{N}$, WEP, and percent TP as WEP, demonstrated homogeneity of variance among facilities (Table 2). As the majority of the measured BHD properties showed homogeneity of variance (Table 2), ANOVA was used to evaluate differences among facilities.

Means of all measured BHD properties differed $(P<0.05)$ among facilities (Table 3). The gravimetric moisture content of BHD in Facility 1 was 9\%, which was lower than in Facility 2 (12.7\%) and 3 (14.7\%), which did not differ (Table 3). Relatedly, in-house humidity can vary within and among houses at the same facility depending on ground moisture outside the house and litter moisture in the house. Facilities are typically constructed by excavating soil from between houses and mounding it where the houses will be constructed to form a raised pad. The remaining lower areas between house pads are graded to create a gentle slope for runoff water to drain away from the production area. If the land between houses is not graded sufficiently to allow for adequate drainage, water can pond and raise the humidity of air adjacent to houses. When this air is pulled into the house during ventilation, it can raise the in-house humidity, which in turn raises the moisture content of the BHD and BL. Additionally, if water lines or drinkers are leaking inside a house, the litter moisture content can be elevated, resulting in more localized increases in humidity. In this study, surface ponding of water was observed between houses at Facility 3, which had the greatest numeric moisture content in the dust. In addition, the height of the 
Table 3. Summary of the effects of facility on mean dust composition.

\begin{tabular}{|c|c|c|c|c|}
\hline \multirow{2}{*}{ Measured Parameter* } & \multirow{2}{*}{$P$} & \multicolumn{3}{|c|}{ Facility } \\
\hline & & 1 & 2 & 3 \\
\hline $\mathrm{H}_{2} \mathrm{O}(\%)$ & $<0.001$ & $9.0 \mathrm{a}^{\dagger}$ & $12.7 \mathrm{~b}$ & $14.7 \mathrm{~b}$ \\
\hline DM (\%) & $<0.001$ & $91.0 \mathrm{a}$ & 87.3b & $85.4 \mathrm{~b}$ \\
\hline $\mathrm{TN}\left(\mathrm{g} \cdot \mathrm{kg}^{-1}\right)$ & $<0.001$ & $133.4 \mathrm{a}$ & $81.3 \mathrm{~b}$ & $101.3 \mathrm{c}$ \\
\hline $\mathrm{C}\left(\mathrm{g} \cdot \mathrm{kg}^{-1}\right)$ & 0.008 & 311.9a & $316.0 \mathrm{a}$ & $335.2 b$ \\
\hline TP $\left(\mathrm{g} \cdot \mathrm{kg}^{-1}\right)$ & $<0.001$ & $14.2 \mathrm{a}$ & $17.2 \mathrm{~b}$ & $15.7 \mathrm{~b}$ \\
\hline $\mathrm{K}\left(\mathrm{g} \cdot \mathrm{kg}^{-1}\right)$ & $<0.001$ & $43.6 \mathrm{a}$ & $29.4 \mathrm{~b}$ & $24.7 \mathrm{~b}$ \\
\hline $\mathrm{Ca}\left(\mathrm{g} \cdot \mathrm{kg}^{-1}\right)$ & $<0.001$ & $15.9 a$ & $26.5 b$ & $12.0 \mathrm{a}$ \\
\hline $\mathrm{NH}_{4}-\mathrm{N}\left(\mathrm{mg} \cdot \mathrm{kg}^{-1}\right)$ & $<0.001$ & $9228 a$ & 3223b & $5257 \mathrm{c}$ \\
\hline $\mathrm{NO}_{3}-\mathrm{N}\left(\mathrm{mg} \cdot \mathrm{kg}^{-1}\right)$ & 0.021 & $61.6 a$ & $402.3 b$ & $476.7 \mathrm{~b}$ \\
\hline WEP (mg $\left.\mathrm{kg}^{-1}\right)$ & $<0.001$ & $5883 a$ & $6580 \mathrm{~b}$ & $4720 \mathrm{a}$ \\
\hline TP as WEP (\%) & $<0.001$ & $41.5 \mathrm{a}$ & $38.5 a$ & $30.5 b$ \\
\hline $\mathrm{pH} 1: 5$ & 0.002 & 7.1a & $7.5 b$ & $7.4 \mathrm{~b}$ \\
\hline
\end{tabular}

* Measured parameters include gravimetric moisture $\left(\mathrm{H}_{2} \mathrm{O}\right)$, dry matter $(\mathrm{DM})$, total nitrogen (TN), carbon (C), total phosphorus (TP), potassium (K), calcium (Ca), ammonium-nitrogen $\left(\mathrm{NH}_{4}-\mathrm{N}\right)$, nitrate-nitrogen $\left(\mathrm{NO}_{3}-\mathrm{N}\right)$, water extractable phosphorus (WEP), total phosphorus as water extractable phosphorus (TP as WEP), and $\mathrm{pH}$. ${ }^{\dagger}$ Different lower case letters in a column indicate significant differences among sample dates $(P<0.05)$.

grass growing between the houses at Facility 3 was over $15 \mathrm{~cm}$, which also contributed transpiration humidity near ventilation intakes, which either did not occur or occurred to a lesser degree at the other two facilities.

Phosphorus is a macronutrient required for healthy bone and cell growth in broiler chickens, and because broilers cannot breakdown phytate-P common in corn (Zea mays L.) and soybean (Glycine max [L.] Merr.), feed is supplemented with mineral $\mathrm{P}$ to ensure birds absorb sufficient quantities of P. However, $\mathrm{P}$ is inefficiently utilized by birds, with about 30\% of ingested P utilized [18]. The remaining P ( 70\%) passes though the bird's digestive tract and is excreted [19]. As TP and WEP are primary contributors to runoff water impairment, quantification of these parameters in BHD is important when considering the potential contribution of $\mathrm{P}$ to runoff from broiler production facilities. Total $\mathrm{P}$ was greater at Facilities 2 and 3, which did not differ, than at Facility 1, while WEP concentrations were greater at Facility 2 than at Facility 1 and 3, which did not differ (Table 3). In contrast, the percentage of TP as WEP was greater at Facility 1 than at Facility 2 and 3, where there was no difference (Table 3).

Combining all BHD samples collected from the three facilities, there was a significant relationship $(P<0.05)$ between WEP and total Ca concentrations of BHD (Figure 2). This suggests that Ca in the BHD might be acting as a carrier for some of the $\mathrm{P}$ by forming Ca-P complexes, which are water soluble. The fact that the percent of TP in BHD that is WEP varies little with facility or fan type (Table 4) reinforces the suggestion that Ca may be acting as a carrier for WEP, rather than influencing the solubility of BHD P. The variation in the Ca concentration of BHD is likely due to feed management, litter bedding material, and number of flocks of poultry birds on the BL.

The remaining BHD properties measured (i.e., $\mathrm{DM}, \mathrm{TN}, \mathrm{NH}_{4}-\mathrm{N}, \mathrm{NO}_{3}-\mathrm{N}, \mathrm{Ca}$, and $\mathrm{K}$ ) varied among the three facilities, with no consistent trends observed (Table 3). Each integrator company creates a unique and proprietary feed mixture for broiler chickens, which varies based on bird age. The tailored feed is designed to promote rapid growth of muscle, the meat produced for human consumption, while maintaining bird health. While corn is the dominant dietary component in broiler feed, other fat and protein sources are added to feed to provide a balanced diet.

\subsection{Dust Composition Differences among Fans within a Single Facility}

Combined across sample dates, BHD composition (i.e., moisture content, dry matter, TN, TP, K, and WEP 


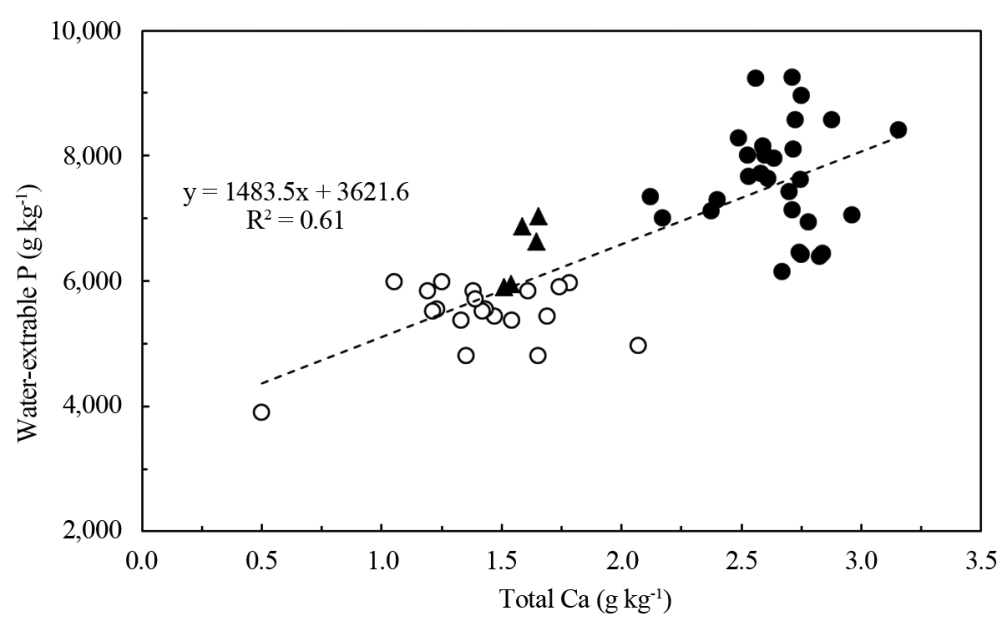

Figure 2. Relationship between water-extractable $\mathrm{P}$ and total Ca concentration of broiler house dust collected from three commercial operating broiler production facilities in northwest AR.

Table 4. Summary of effect of static fan number on dust composition differences among fans at Facility 2, House 4.

\begin{tabular}{|c|c|c|c|c|c|c|c|}
\hline \multirow{2}{*}{ Fan/Statistic } & $\mathrm{H}_{2} \mathrm{O}^{*}$ & $\mathrm{DM}$ & $\mathrm{TN}$ & ТP & K & \multirow{2}{*}{$\begin{array}{c}\text { WEP } \\
\left(\mathrm{mg} \cdot \mathrm{kg}^{-1}\right)\end{array}$} & \multirow{2}{*}{$\begin{array}{l}\text { TP as WEP } \\
(\%)\end{array}$} \\
\hline & \multicolumn{2}{|c|}{$\%$} & \multicolumn{3}{|c|}{$\mathrm{g} \cdot \mathrm{kg}^{-1}$} & & \\
\hline 1 & 13.0 & 87.0 & 92.8 & 11.7 & 22.5 & 6406 & 57 \\
\hline 2 & 12.5 & 87.5 & 81.7 & 12.1 & 23.2 & 5714 & 47 \\
\hline 3 & 12.9 & 87.1 & 75.9 & 12.8 & 21.9 & 5857 & 47 \\
\hline 4 & 14.0 & 86.0 & 87.7 & 13.7 & 22.6 & 6031 & 45 \\
\hline$P^{\dagger}$ & 0.97 & 0.97 & 0.28 & 0.88 & 0.97 & 0.94 & 0.08 \\
\hline Overall Mean & 13.1 & 86.9 & 84.5 & 12.6 & 22.5 & 6002 & 49 \\
\hline
\end{tabular}

*Measured parameters include gravimetric moisture $\left(\mathrm{H}_{2} \mathrm{O}\right)$, dry matter $(\mathrm{DM})$, total nitrogen (TN), total phosphorus (TP), potassium (K), water extractable phosphorus (WEP), and total phosphorus as water extractable phosphorus (TP as WEP). ${ }^{\dagger} P$-value for effect of fan.

concentrations, and the percentage of TP as WEP) did not differ among sidewall fans in House 4 at Facility 2 (Table 4). These results indicate that BHD composition was spatially uniform among fans within this single broiler house. This consistency in BHD composition among fans indicates that, although fans were installed at different locations along a wall of a house, and they operated at different times and for different purposes throughout a flock, the particulate matter that became airborne and was transported to the fans was uniform. Uniformity of BHD composition among fans within a single facility was not expected since the birds did not occupy the entire house throughout a flock production cycle and, as a result, manure was not deposited uniformly throughout the house.

Though BHD composition did not differ among fans within a single facility (Table 4), combined across fans in House 4 at Facility 2, BHD composition varied with time (Table 5). The moisture contents of dust samples collected in January 2013 were greater $(P<0.05)$ than those in April through October 2012 (Table 5). This was likely due to decreased ventilation during cooler winter weather to retain heat and reduce energy costs. The average moisture of the BHD collected in January 2013 was 21.6\% (Table 5), slightly less than the average moisture content of the BL (Table 6). However, the average moisture content across all of the dust samples from the five flocks, $13.1 \%$, was approximately half that of BL [3]. Potassium concentrations in dust samples collected in April through August 2012 were greater $(P<0.05)$ than those in October and January (Table 5). The differences in BHD K concentrations were likely a result of dietary changes based on the type of grains and supplements available. 
Table 5. Summary of effect of sample date on dust composition differences at Facility 2, House 4.

\begin{tabular}{ccccccc}
\hline Sample Date & $\mathrm{H}_{2} \mathrm{O}^{*}(\%)$ & $\begin{array}{c}\mathrm{TN} \\
\left(\mathrm{g} \cdot \mathrm{kg}^{-1}\right)\end{array}$ & $\begin{array}{c}\mathrm{TP} \\
\left(\mathrm{g} \cdot \mathrm{kg}^{-1}\right)\end{array}$ & $\begin{array}{c}\mathrm{K} \\
\left(\mathrm{g} \cdot \mathrm{kg}^{-1}\right)\end{array}$ & $\begin{array}{c}\text { WEP } \\
\left(\mathrm{mg} \cdot \mathrm{kg}^{-1}\right)\end{array}$ & $\begin{array}{c}\mathrm{TP} \text { as } \\
\text { WEP }(\%)\end{array}$ \\
\hline $4 / 18 / 2012$ & $11.1 \mathrm{a}^{\dagger}$ & 97.8 & 16.2 & $25.8 \mathrm{a}$ & 6480 & 41 \\
$6 / 20 / 2012$ & $11.1 \mathrm{a}$ & 79.2 & 15.7 & $25.8 \mathrm{a}$ & 7130 & 46 \\
$8 / 23 / 2012$ & $10.9 \mathrm{a}$ & 80.9 & 14.8 & $25.5 \mathrm{a}$ & 7926 & 54 \\
$10 / 31 / 2012$ & $10.9 \mathrm{a}$ & 77.1 & 9.2 & $18.3 \mathrm{~b}$ & 4724 & 51 \\
$1 / 10 / 2013$ & $21.6 \mathrm{~b}$ & 87.5 & 7.0 & $17.3 \mathrm{~b}$ & 3750 & 53 \\
\hline
\end{tabular}

*Measured parameters include gravimetric moisture $\left(\mathrm{H}_{2} \mathrm{O}\right)$, total nitrogen $(\mathrm{TN})$, total phosphorus $(\mathrm{TP})$, potassium $(\mathrm{K})$, water extractable phosphorus (WEP), and total phosphorus as water extractable phosphorus (TP as WEP). ${ }^{\dagger}$ Different lower case letters in a column indicate significant differences among sample dates $(P<0.05)$.

In contrast to the moisture content and $\mathrm{K}$ concentrations, combined across fans, TN, TP, and WEP concentrations in the BHD did not differ over time, and averaged 84, 13, and $6002 \mathrm{~g} \cdot \mathrm{kg}^{-1}$, respectively (Table 5). Similarly, the percentage of TP as WEP remained relatively constant with time at almost 50\%, irrespective of sample date (Table 5). Results show that differential fan usage over time affects some, but not all of the BHD component concentrations measured over time.

\subsection{Composition Differences between Broiler House Dust and Litter}

Broiler house dust is composed of lighter-weight particles of BL and feed. Broiler litter particles are detached and transported as a result of bird scratching and ventilation airflow. Loosely bound, pelletized feed separates into smaller particles when feed augers operate to deliver feed to feed pans. Both BL and feed particles become airborne and are transported with ventilation airflow. It was hypothesized that the chemical composition of BHD would thus be similar to the BL from which it originated. However, most of the BHD properties differed significantly $(P<0.05)$ from that in BL from which the dust originated (Table 6).

The average moisture content of the BL from each facility was at least 1.9 times greater than the BHD from the same facility (Table 6). In fact, BHD had the appearance of flour, while BL was similar to moist, mediumtextured compost.

The primary focus of the comparison of BHD to BL was on the parameters known to impair water quality by accelerating eutrophication (i.e., P and N) [20] [21]. Average TP, WEP, and TN concentrations of BHD were at least 1.2, 1.6, and 3.0 times greater, respectively, than of BL from the same facility (Table 6). Of particular importance to potential nutrient runoff is the proportion of BHD TP as WEP, which was, on average, 1.6 times greater than in BL (Table 6).

These results have direct implications to the potential for nutrient enrichment of runoff from broiler production facilities, compared with runoff from fields to which litter has been applied. While BL is land applied as a fertilizer to crop and hayland, BHD is deposited in concentrated areas adjacent to the fan exhaust of production houses. On a per unit area basis, the amount of BHD deposited on a $25-\mathrm{m}^{2}$ area adjacent to a sidewall/tunnel fan, approximately $4500 \mathrm{~kg} \cdot \mathrm{ha}^{-1}$ (or 2 tons ac $\mathrm{ac}^{-1}$ ), is similar to BL routinely applied to pastures in northwest AR [3] [4]. However, due to the greater concentration of $\mathrm{P}$ and $\mathrm{N}$ in BHD than BL, this equated to a deposition of 474 and $71 \mathrm{~kg} \cdot \mathrm{ha}^{-1}$ as TN and TP, respectively, as BHD (average of the three facilities) and 152 and $55 \mathrm{~kg} \cdot \mathrm{ha}^{-1} \mathrm{as}$ BL that is potentially available for transport in surface runoff.

\section{Conclusions}

The nutrients that contribute to increased rates of surface water eutrophication, $\mathrm{P}$ and N, are present in BHD. There were distinct differences among integrator/producer facilities in nutrient concentrations of BHD collected from active broiler production houses. This was likely due to differences in dietary mixtures used by integrators, bedding material, and other in-house management protocols specific to each producer. Therefore, facilities producing for different integrators should be evaluated for their unique potential to contribute $\mathrm{P}$ and $\mathrm{N}$ to stormwater runoff.

Although the concentrations of TP, WEP, and TN in BHD varied among facilities, these concentrations were consistently greater in BHD than in the source BL from the same facility. Additionally, the moisture content of 
Table 6. Summary of the effect of facility on broiler house dust (BHD) and broiler litter (BL) composition.

\begin{tabular}{|c|c|c|c|c|c|c|c|}
\hline \multirow{2}{*}{ Measured Parameter* } & \multirow{2}{*}{$P^{\dagger}$} & \multicolumn{2}{|c|}{ Facility 1} & \multicolumn{2}{|c|}{ Facility 2} & \multicolumn{2}{|c|}{ Facility 3} \\
\hline & & BHD & BL & BHD & BL & BHD & BL \\
\hline $\mathrm{H}_{2} \mathrm{O}(\%)$ & 0.01 & 9.0 & 22.6 & 12.7 & 26.6 & 14.7 & 28.5 \\
\hline $\mathrm{TN}\left(\mathrm{g} \cdot \mathrm{kg}^{-1}\right)$ & 0.01 & 133.4 & 41.9 & 81.3 & 27.4 & 101.3 & 31.8 \\
\hline $\mathrm{C}\left(\mathrm{g} \cdot \mathrm{kg}^{-1}\right)$ & 0.01 & 311.9 & 285.6 & 316.0 & 251.6 & 335.2 & 247.3 \\
\hline TP $\left(g \cdot \mathrm{kg}^{-1}\right)$ & 0.03 & 14.2 & 12.1 & 17.2 & 13.2 & 15.7 & 11.2 \\
\hline $\mathrm{K}\left(\mathrm{g} \cdot \mathrm{kg}^{-1}\right)$ & 0.20 & 43.6 & 24.8 & 29.4 & 23.1 & 24.7 & 23.1 \\
\hline $\mathrm{Ca}\left(\mathrm{g} \cdot \mathrm{kg}^{-1}\right)$ & 0.79 & 15.9 & 17.8 & 26.5 & 26.2 & 12.0 & 15.1 \\
\hline WEP $\left(\mathrm{mg} \cdot \mathrm{kg}^{-1}\right)$ & 0.01 & 5883 & 2711 & 6580 & 2700 & 4720 & 2944 \\
\hline TP as WEP (\%) & 0.02 & 41.5 & 22.4 & 38.2 & 20.5 & 30.0 & 26.3 \\
\hline pH 1:5 & 0.004 & 7.1 & 8.1 & 7.5 & 8.5 & 7.4 & 8.6 \\
\hline
\end{tabular}

*Measured parameters include gravimetric moisture $\left(\mathrm{H}_{2} \mathrm{O}\right)$, total nitrogen $(\mathrm{TN})$, carbon $(\mathrm{C})$, total phosphorus (TP), potassium (K), calcium $(\mathrm{Ca})$, water extractable phosphorus (WEP), total phosphorus as water extractable phosphorus (TP as WEP), and pH. ${ }^{\dagger} P$-value for effect of sample source (BHD vs BL).

the BHD was approximately half that of the BL from the same facility. Due to the variability of moisture content, TP, WEP, and TN between BHD and BL, research that has been conducted on BL to assess the potential for nutrient transport in stormwater runoff from poultry production facilities cannot be considered equivalent to using BHD. Therefore, it is important to evaluate the chemical composition, volume, and weight of BHD exhausted from house fans, and to assess the potential for BHD nutrients to be transported to nearby streams and rivers.

\section{Acknowledgements}

This research acknowledges the support of the USGS 104B program funding. The authors gratefully appreciated the collaboration of owners and managers of each production facility allowing access to broiler houses, which made this study possible.

\section{References}

[1] United States District Court in West Virginia in Alt, et al. v. EPA, et al. (2013) The Scope of the Clean Water Act Exemption from the Term Points Source for “Agricultural Stormwater Discharges” in October 23rd, 2013 Opinion. Civil Action No. 2: 12-CV-42. 26 p.

[2] United States Department of Agriculture, National Agricultural Statistics Service (2015) Poultry: Production and Value-2014 Summary. http://www.usda.gov/nass/PUBS/TODAYRPT/plva0415.pdf

[3] Herron, S., Sharpley, A.N., Watkins, S. and Daniels, M. (2012) Poultry Litter Management in the Illinois River Watershed of Arkansas and Oklahoma. http://www.uaex.edu/Other_Areas/publications/PDF/FSA-9535.pdf

[4] Sharpley, A.N., Richards, R.P., Herron, S. and Baker, D.B. (2012) Can Production and Environmental Goals Coexist in Phosphorus-Based Farm Management? Journal of Soil \& Water Conservation, 67, 149-193.

[5] Oklahoma Farm Bureau Legal Foundation (2010) Poultry Litigation Summary. http://ofblegalfoundation.org/litigation/item. aspx?archive=0\&page=8415.htm\&id=8415

[6] United States District Court for the Northeastern District of Oklahoma vs. Tyson Foods, Inc., et al. (2003) Order Approving Settlement Agreement. https://ecf.oknd.uscourts.gov/cgi-bin/DisplayPDF.pl?dm_id=858914\&dm_seq=0

[7] Wicklen, G.L. and Czarick, M. (1997) Particulate Emissions from Poultry Housing. ASAE Annual International Meeting, Minneapolis Convention Center, Minneapolis.

[8] Burns, R., Li, H., Moody, L., Xin, H., Gates, R., Overhults, D. and Earnest, J. (2008) Quantification of Particulate Emissions from Broiler Houses in the Southeastern United States. Proceedings of the 2008 Livestock Environment VIII Conference, ASABE Publication 701P0408.

[9] United States Department of Agriculture, National Agricultural Statistics Service (2015) Poultry Summary. http://www.uspoultry.org/economic_data/

[10] Wolf, A., Watson, M., and Wolf, N. (2003) Digestion and Dissolution Methods for P, K, Ca, Mg and Trace Elements. 
In: Peters, J., Ed., Recommended Methods of Manure Analysis, University of Wisconsin-Extension, Madison, 30-38.

[11] Nelson, D.W. and Sommers, L.E. (1996) Total Carbon, Organic Carbon, and Organic Matter. In: Sparks, D.L., Ed., Methods of Soil Analysis, Part 3: Chemical Methods, American Society of Agronomy, Madison, 961-1010.

[12] Self-Davis, M.L., Moore, P.A. and Joern, B.C. (2009) Water- or Dilute Salt-Extractable Phosphorus in Soil. In: Kovar, J.L. and Pierzynski, G.M., Eds., Methods for Phosphorus Analysis for Soils, Sediments, Residuals, and Waters, Southern Cooperative Series Bulletin, Virginia Tech University, Blacksburg, 22-24.

[13] Wolf, A.M., Moore, P.A., Kleinman, P.J.A. and Sullivan, D.M. (2009) Water Extractable Phosphorus in Animal Manures and Biosolids: Bioavailable Phosphorus in Soil. https://sera17dotorg.files.wordpress.com/2015/02/sera-17-methods-for-p-2009.pdf

[14] United State Department of Agriculture, Natural Resources Conservation Service (2011) Conservation Practice Standard, Nutrient Management 590. http://www.nrcs.usda.gov/Internet/FSE_DOCUMENTS/stelprdb1046177.pdf

[15] Peters, J. (2003) Recommended Methods of Manure Analysis. Cooperative Extension Publishing Operations, Madison.

[16] Daigh, A.L., Brye, K.R., Sharpley, A.N., Miller, D. and Gbur, E. (2010) Broiler Litter Composition as Affected by Water Extractant, Dilution Ratio, and Extraction Time. Communications in Soil Science \& Plant Analysis, 41, 23402357. http://dx.doi.org/10.1080/00103624.2010.508098

[17] Sharpley, A.N. and Moyer, B. (2000) Forms of Phosphorus in Manures and Composts and Their Dissolution during Rainfall. Journal of Environmental Quality, 29, 1462-1469. http://dx.doi.org/10.2134/jeq2000.00472425002900050012x

[18] Applegate, T.J., Joern, B.C., Nussbaum-Wagler, D.L. and Angel, R. (2003) Water Soluble Phosphorus in Fresh Broiler Litter Is Dependent upon Phosphorus Concentration Fed but Not on Fungal Phytase Supplementation. Poultry Science, 82, 1024-1029. http://dx.doi.org/10.1093/ps/82.6.1024

[19] Patterson, P.H., Moore, P.A. and Angel, R. (2005) Phosphorus and Poultry Nutrition. In: Sims, J.T. and Sharpley, A.N., Eds., Phosphorus: Agriculture and the Environment, American Society of Agronomy, Monograph 46, Madison, 685727.

[20] Carpenter, S.R. (2008) Phosphorus Control Is Critical to Mitigating Eutrophication. Proceedings of the National Academy of Sciences, 105, 11039-11040. http://dx.doi.org/10.1073/pnas.0806112105

[21] Schindler, D.W., Hecky, R.E., Findlay, D.L., Stainton, M.P., Parker, B.R., Paterson, M.J., Beaty, K.G., Lyng, M. and Kasian, S.E. (2008) Eutrophication of Lakes Cannot Be Controlled by Reducing Nitrogen Input: Results of a 37-Year Whole-Ecosystem Experiment. Proceedings of the National Academy of Sciences, 105, 11254-11258. http://dx.doi.org/10.1073/pnas.0805108105 